\title{
「心理情報メンンタルヘルス，理系教育」特集にあたって*
}

\author{
瀬尾 和哉**
}

\section{Psychology Information Studies, Mental Health and Science Education}

\author{
Kazuya SEO
}

今回の特集号には，5件の記事が掲載されている。心 理情報，メンタルヘルスに関する特集記事が 3 件，理系 教育に関する記事が 2 件である。これらの分野に関係す る最新の動向を紹介する目的で，各方面の方々に執筆を お願いした。可視化情報学会が元々の工学分野から他分 野へ守備範囲を広げる試みの一つであろう。

心理情報, メンタルヘルスと言えば, 教員養成系学部 では花形である。心理系は文系ではあるが，その実は統 計学に基礎をおく理系的な要素も含んでおり，近年の計 算機の発達と相まって，新たな局面を迎えている。

「オンラインカウンセリングシステムにおける GUI」 では，海外赴任者のメンタルヘルスケアを行う目的で， オンラインによるカウンセリングシステムの開発がおこ なわれている。セキュリティの強固なシステムが構築さ れ，そのシステムをアンケート調査により評価し，さら に評価結果を反映した GUI 式オンラインカウンセリン グシステムが実現されている。

「Web カウンセリングシステムにおける描画検査」で は，Web ブラウザを使用したバウムテストシステムが 紹介されている。バウムテストとは，描かれた樹木画か ら被験者の欲求や感情などの無意識な側面を映し出す心 理検査である。このシステムでは，樹木の配置や大きさ 等のカウンセリング要素に加えて, SVG（Scalable Vector Graphics）のアニメーション機能により，被験 者の描画手順を時系列に再現できるため, 樹木画の書き 順もカウンセリング要素になる。情報処理技術がカウン セリングにも役立つ良い例である。

「異常時対応能力向上プログラムにおける列車運転行 動の可視化」では, 運転士訓練用の列車運転シミュレー タが紹介されている。このシミュレータでは, 次々とイ ベントを起し，運転士にストレスを与える。人間の利用 可能な注意の量には限界がある為, 運転士はヒューマン エラーを起こしてしまう。これらのエラーデータを運転 直後の運転士に提示し，どのような環境下でどのような
運転行動をとったか，を客観的に可視化できるように なっている。

理科教育等も教員養成系学部の領域である。しかし， 教員養成系学部の学生は文系マインドであり，将来の理 科教員を夢見て入学してきたにもかかわらず，特に物理 には苦手意識があるようである。

$\lceil 1 / 1000$ 秒の世界が拓く ICT を活用した理科教育」 では，1/1000 秒オーダの fps をもつデジタルカメラを 使用し，物理教育に使用する教材例が紹介されている. ミリ秒の世界を視覚化し, 生徒が能動的に授業に参加す るアクティブ・ラーニング型の授業の実行により，学習 者は科学的概念の形成を確実に出来るようになった。こ のデジタルカメラを使用すると，実体験に即した理科実 験が可能になり，また工夫次第で授業準備時間を余りか けずに豊かな理科教育が実現できる可能性が広がってい る。著者も同じカメラを持っている，あのカメラにトリ ガ機能があれば，と常に思っている（ムービー内にトリ ガとなる LEDの光を撮影しておけば，他の計測系との 同期は可能.）が，とにかく 10 万円少しで，高速度撮影 できるデジタルカメラは大変ありがたい.

「技術科教育の現状」では，まず現在の日本の若年層 の科学技術離れについて概観した後，技術科教育と理科 教育の違いを述べ，技術科教育の果たすべき役割につい て解説している。さらに，2008 年 3 月に公示された新 学習指導要領に基づき，技術科教育においても可視化が 本質的で，重要であることを指摘している．近年の工学 部志望者数の減少率は，少子化の勢いを超えている. デー夕で改めて，現状を確認すると衝撃を感じる。

本特集が，可視化情報学会員の皆様の琴線に触れれば 幸いである。

\footnotetext{
* 原稿受付 2010 年 3 月 14 日

** 正会員山形大学地域教育文化学部 ( ₹ 990-8560 山形市小白川 1-4-12, E-mail : seo@e.yamagata-u.ac.jp)
} 